medRxiv preprint doi: https://doi.org/10.1101/2021.01.24.21250393; this version posted January 26, 2021. The copyright holder for this preprint (which was not certified by peer review) is the author/funder, who has granted medRxiv a license to display the preprint in

All rights reserved. No reuse allowed without permission.

\title{
Title: Chest wall abnormalities in Swiss childhood cancer survivors
}

Rahel Kasteler ${ }^{1,2}$; Christa Lichtensteiger ${ }^{1}$; Christina Schindera ${ }^{1,3}$; Marc Ansari ${ }^{4,5}$;

Claudia E. Kuehni ${ }^{1,2}$; for the Swiss Pediatric Oncology Group (SPOG)a.

${ }^{1}$ Childhood Cancer Registry, Institute of Social and Preventive Medicine, University of Bern, Switzerland.

${ }^{2}$ Department of Pediatrics, Inselspital, Bern University Hospital, University of Bern, Switzerland

${ }^{3}$ Division of Pediatric Hematology/Oncology, University Children`s Hospital Basel, Switzerland

${ }^{4}$ Department of Women, Child and Adolescent, Pediatric Oncology and Hematology Unit, Geneva University Hospital, Switzerland

${ }^{5}$ Platform of Pediatric Onco-Hematology research (CANSEARCH Research Laboratory), Department of Pediatrics, Gynecology, and Obstetrics, University of Geneva, Geneva, Switzerland

a Swiss Pediatric Oncology Group (SPOG) Scientific Committee: Prof. Dr. med. J.

Rössler, Bern; Prof. Dr. med. M. Ansari, Geneva; Prof. Dr. med. M. Beck Popovic, Lausanne; Dr. med. P. Brazzola, Bellinzona; Dr. med. J. Greiner, St. Gallen; Prof. Dr. med. F. Niggli, Zürich; Dr. med. H. Hengartner, St. Gallen; Prof. Dr. med. C. Kuehni, Bern; Dr. med. F. Schilling, Lucerne; Dr. med. K. Scheinemann, Aarau; Prof. Dr. med. N. von der Weid, Basel; Dr. N. Gerber, Zürich. 
medRxiv preprint doi: https://doi.org/10.1101/2021.01.24.21250393; this version posted January 26, 2021. The copyright holder for this preprint (which was not certified by peer review) is the author/funder, who has granted medRxiv a license to display the preprint in

All rights reserved. No reuse allowed without permission.

\section{Corresponding author}

Claudia E. Kuehni Prof MD MSc

Childhood Cancer Registry

Institute of Social and Preventive Medicine

University of Bern

Mittelstrasse 43

3012 Bern

Switzerland

E-mail: claudia.kuehni@ispm.unibe.ch

Telephone: +41316313507

Facsimile: +41316313520 
medRxiv preprint doi: https://doi.org/10.1101/2021.01.24.21250393; this version posted January 26, 2021. The copyright holder for this preprint (which was not certified by peer review) is the author/funder, who has granted medRxiv a license to display the preprint in

All rights reserved. No reuse allowed without permission.

\section{Declaration}

\section{Ethics approval and consent to participate}

The Ethics Committee of the Canton of Bern approved the SCCR and the SCCSS (KEK-BE: 166/2014), and the Swiss Childhood Cancer Survivor Study is registered at ClinicalTrials.gov (identifier: NCT03297034).

\section{Consent for publication}

Not applicable

\section{Availability of data and materials}

The datasets generated and/or analysed during the current study are not publicly available due to the local data safety agreement but are available from the corresponding author on reasonable request.

\section{Competing interests}

The authors declare that they have no competing interests

\section{Funding}

This study was supported by the Swiss Cancer League (KFS-4157-02-2017 and KLS-3886-02-2016). The funders had no role in study design, data collection and analysis, decision to publish, or preparation of the manuscript.

\section{Authors' contributions}

RK conception, acquisition, analysis and interpretation of data, drafted and revised manuscript

$\mathrm{CL}$ acquisition and interpretation of data, substantially revised manuscript CS interpretation of data, substantially revised manuscript MA substantially revised manuscript 
medRxiv preprint doi: https://doi.org/10.1101/2021.01.24.21250393; this version posted January 26, 2021. The copyright holder for this preprint (which was not certified by peer review) is the author/funder, who has granted medRxiv a license to display the preprint in All rights reserved. No reuse allowed without permission.

CEK conception, acquisition, analysis and interpretation of data, substantially revised manuscript

\section{Acknowledgements}

We thank all childhood cancer survivors and families for participating in our survey. We thank the study team of the SCCSS (Fabiën Belle, Rahel Kuonen, Jana Remlinger, Cornelia Rebholz, Corina Rueegg, Grit Sommer, Annette Weiss, Laura Wengenroth). We would like to thank Christopher Ritter for his editorial assistance. 
medRxiv preprint doi: https://doi.org/10.1101/2021.01.24.21250393; this version posted January 26, 2021. The copyright holder for this preprint (which was not certified by peer review) is the author/funder, who has granted medRxiv a license to display the preprint in All rights reserved. No reuse allowed without permission.

\section{Abbreviations:}

$\mathrm{Cl}$

Confidence interval

CNS

Central nervous system

IQR

Interquartile range

$\mathrm{N}$

Number

OR

Odds ratio

$\mathrm{P}$

P-value

SCCR

Swiss Childhood Cancer Registry

sccss

Swiss Childhood Cancer Survivor Study 
medRxiv preprint doi: https://doi.org/10.1101/2021.01.24.21250393; this version posted January 26, 2021. The copyright holder for this preprint (which was not certified by peer review) is the author/funder, who has granted medRxiv a license to display the preprint in

All rights reserved. No reuse allowed without permission.

\section{Abstract (245/350 words)}

Background: Chest wall abnormalities are a poorly studied complication after treatment for childhood cancer. Chest wall abnormalities are not well described in the literature, and little is known on the impact on daily life of survivors.

Methods: We investigated chest wall abnormalities in the nationwide, populationbased cohort study (Swiss Childhood Cancer Survivor Study) with a questionnaire survey to describe prevalence and risk factors. We then interviewed a nested sample of survivors to understand types of chest wall abnormalities and their impact on daily life of survivors.

Results: 48 of $2,382(95 \% \mathrm{Cl} 2 \%-3 \%)$ survivors reported a chest wall abnormality. Risk factors were older age at cancer diagnosis (16-20 years; OR 2.5, 95\%Cl 1.06.1), lymphoma (OR 3.8, 95\% $\mathrm{Cl} 1.2-11.4$ ), and central nervous system tumors (OR 9.5, 95\%Cl 3.0-30.1) as underlying disease, and treatment with thoracic radiotherapy (OR $2.0,95 \% \mathrm{Cl} 1.0-4.2)$, surgery to the chest (OR 4.5, 95\%Cl $1.8-$ 11.5), or chemotherapy (OR 2.9, 95\% $\mathrm{Cl} 1.0-8.1)$. The nature of the chest wall abnormalities varied and included thoracic wall deformities (30\%), deformations of the spine (5\%) or both (55\%), and scars (10\%). Chest wall abnormalities affected the daily life in two thirds (13/20) of those who reported these problems, and 15 (75\%) had required chest wall abnormalities-related medical attention.

Conclusion: It is important that during follow-up care physicians pay attention to chest wall abnormalities, which are rare late-effect of cancer treatment, but can considerably affect well-being of cancer survivors.

Key words: chest wall abnormality, childhood cancer survivors, late effects, cancer treatment 
medRxiv preprint doi: https://doi.org/10.1101/2021.01.24.21250393; this version posted January 26, 2021. The copyright holder for this preprint (which was not certified by peer review) is the author/funder, who has granted medRxiv a license to display the preprint in

All rights reserved. No reuse allowed without permission.

\section{Background}

Chest wall abnormalities have been reported in a widely variable proportion of childhood cancer survivors, but available studies were small, including 16 to 143 participants, ${ }^{1-9}$ or focused on patients with selected cancer diagnoses like chest wall sarcoma,${ }^{1}$ central nervous system (CNS) tumours, ${ }^{10}$ neuroblastoma ${ }^{2,9}$ or Wilms tumour. ${ }^{3,4}$ Some studies reported on specific cancer treatments like thoracic radiotherapy, radiotherapy to the spine,${ }^{6}$ abdominal radiotherapy ${ }^{7,8}$ or surgical interventions for solid tumours. ${ }^{5}$ Such data are not representative for the entire population of childhood cancer survivors. In large, cross-sectional studies, $1.4 \%{ }^{11}$ (North America, multicenter study) to $2.0 \%{ }^{12}$ (Switzerland, population based study) of survivors reported chest wall abnormalities in questionnaire surveys. ${ }^{10-12}$ Those investigations were questionnaire-based and used one single question on chest wall abnormalities. This did not allow to understand the nature of chest wall abnormalities as no exact definition was attached to the question. Chest wall abnormalities could include thoracic wall and spinal deformities, breast asymmetries, or scars, and the term may not have been clear to some participants. No study investigated whether and how chest wall abnormalities affect the daily life of survivors and if medical care is needed.

We approached these uncertainties by assessing the prevalence of chest wall abnormalities reported by survivors in Switzerland and investigating risk factors. We also interviewed a nested sample of survivors to understand the nature of the reported chest wall abnormalities and impact on daily life. Finally, we conducted a systematic review of the available literature on chest wall abnormalities in childhood cancer survivors. 
medRxiv preprint doi: https://doi.org/10.1101/2021.01.24.21250393; this version posted January 26, 2021. The copyright holder for this preprint (which was not certified by peer review) is the author/funder, who has granted medRxiv a license to display the preprint in

\section{Methods}

\section{Swiss Childhood Cancer Survivor Study}

The Swiss Childhood Cancer Survivor Study (SCCSS) is a population-based, long-term follow-up study of patients registered in the Swiss Childhood Cancer Registry (SCCR, www.childhoodcancerregistry.ch). Participants had been diagnosed with leukemia, lymphoma, CNS tumors, malignant solid tumors, or Langerhans cell histiocytosis since 1976 and before the age of 21 years.

Participants, who had survived $\geq 5$ years since initial cancer diagnosis and were alive at the time of the study, ${ }^{13,14}$ received a questionnaire between 2007 and 2013. Nonresponders received a second copy of the questionnaire four to six weeks later. If they again did not answer, we contacted them by phone. In total 2,382 survivors replied (Supplementary figure S1). Detailed methods of the SCCSS have been published. ${ }^{12-14}$

\section{Outcome: Chest wall abnormalities}

The SCCSS questionnaire, like the North Amercian ${ }^{15}$ and British ${ }^{16}$ Childhood Cancer Survivor Studies, includes one question on chest wall abnormalities in the section on pulmonary health: "Have you ever been told by a doctor that you have or have had changes on your thorax and/or ribs?" and possible answers included ever in live (yes/no), since when (year), currently (yes/no) (Supplementary figure S2).

\section{Validation of outcome by telephone interview}

In a nested follow-up study, we sent a letter to all survivors who had reported a chest wall abnormality in the questionnaire to invite them to take part in a telephone interview. All those were at least 18 years old, still alive, had 
medRxiv preprint doi: https://doi.org/10.1101/2021.01.24.21250393; this version posted January 26, 2021. The copyright holder for this preprint (which was not certified by peer review) is the author/funder, who has granted medRxiv a license to display the preprint in

consented to participation in further studies and had a valid telephone number. Survivors were contacted by telephone between July 2017 and September 2017 by one investigator (CL) (Supplementary figure S1). The purpose of the structured interview was to determine the medical problems underlying the chest wall abnormalities. We sought information on 1) deformations of the chest wall that included asymmetric chest wall, pectus excavatum, pectus carinatum, completely or partially missing ribs, deformation of the breast, muscular abnormalities or other deformations of the chest wall or ribs, 2) deformations of the spine including scoliosis, hyperkyphosis, hyperlordosis or other deformations of the spine, and 3) scars on the chest wall. We also asked about the impact of chest wall abnormalities on daily life which could include general complaints as well as cosmetic problems, respiration problems, flexibility impairments, pain because of the chest wall abnormalities, and impairment in activities of daily living. We also asked whether medical attention - consultation with a physician, diagnostic investigations, operations and physiotherapy - had been sought. The questionnaire used for the interview is available on request.

The Ethics Committee of the Canton of Bern approved the SCCR and the SCCSS (KEK-BE: 166/2014), and the Swiss Childhood Cancer Survivor Study is registered at ClinicalTrials.gov (identifier: NCT03297034).

\section{Covariates: Demographic and cancer-related characteristics}

We obtained cancer characteristics from the SCCR including age at diagnosis, year of diagnosis, cancer diagnosis according to the International Classification of Childhood Cancer, 3rd edition ${ }^{17}$, and details on radiotherapy, surgery, and chemotherapy. We combined total body irradiation, mantle field radiation, and radiation to the thorax, lungs, mediastinum, or thoracic spine to thoracic radiotherapy 
medRxiv preprint doi: https://doi.org/10.1101/2021.01.24.21250393; this version posted January 26, 2021. The copyright holder for this preprint (which was not certified by peer review) is the author/funder, who has granted medRxiv a license to display the preprint in

All rights reserved. No reuse allowed without permission.

(yes/no). Surgery to the chest (yes/no) included the clavicles, scapulae and ribs, tumor excision from soft tissue on thorax, thoracic muscles, thoracic spine, and tumor or lymph node biopsies on the chest wall.

\section{Statistical analysis}

We reported prevalence of chest wall abnormalities overall and stratified by sex, age at cancer diagnosis $(0-5,6-10,11-15,16-20)$, years of diagnosis (1976-1990, 1991-2005), cancer diagnosis (leukemia, lymphoma, CNS tumor, other tumors) and cancer treatment (thoracic radiotherapy (yes, no), surgery to the chest (yes, no), any chemotherapy (yes, no)). We identified demographic and cancer-related risk factors for chest wall abnormalities using univariable and multivariable logistic regression. All analyses were done in Stata (Version 14; Stata Corporation, Austin, TX).

\section{Systematic literature review}

We conducted a literature review searching for relevant articles in the two bibliographic databases PubMed and Embase Ovid, last updated December

31th 2019. Both databases were searched using thesaurus terms $(\mathrm{MeSH}$, Emtree) and textwords. We applied restrictions to language and searched studies on humans only, and excluded from the search conference abstracts, letters to the editor and editorials. To retrieve further relevant publications, we checked the reference lists of studies included and added Google scholar for a full-text search. An information specialist from the University Library of Bern was consulted to set up the search strategies in order to ensure optimal data acquisition.

The search results were screened in two steps by two independent reviewers (RK, CL) and assessed according to relevance and eligibility criteria 
medRxiv preprint doi: https://doi.org/10.1101/2021.01.24.21250393; this version posted January 26, 2021. The copyright holder for this preprint (which was not certified by peer review) is the author/funder, who has granted medRxiv a license to display the preprint in

All rights reserved. No reuse allowed without permission.

(PRISMA flow diagram). Additional articles were searched by screening the reference list of suitable systematic reviews found in the two databases. For details on search strategies and search platforms, see Supplementary Text and Supplementary figure S3.

\section{Results}

\section{Prevalence and risk factors of chest wall abnormalities}

Among 2,382 survivors who participated in the SCCSS, $2 \%(48 / 2,382)$ reported a chest wall abnormality (95\% confidence interval [95\% Cl] 1.5-2.7). Male survivors were more often affected $(2.5 \%, 95 \% \mathrm{Cl} 1.8-3.5)$ than females $(1.4 \%, 95 \% \mathrm{Cl} 0.8-2.3)$ (table 1). Median age at study was 31 years (interquartile range $[\mathrm{IQR}] 25-38)$ and survivors who were older at cancer diagnosis (16-20 years, $4.2 \%, 95 \% \mathrm{Cl} 2.2-7.9$ ) had a higher prevalence of chest wall abnormalities compared to those who were younger. Prevalence did not change over time, being $2 \%$ and $2.1 \%$ in the periods of $1976-1990$ and $1991-2005$. When comparing underlying diagnoses, chest wall abnormalities were most frequently reported by survivors of lymphoma $(3.7 \%, 95 \% \mathrm{Cl} 2.3-6.0)$ and $\mathrm{CNS}$ tumors $(3.8 \%, 95 \% \mathrm{Cl} 2.2-6.4)$, but rarely by participants treated for leukemia $(0.6 \%, 95 \% \mathrm{Cl} 0.2-1.5)$. Nearly $8 \%$ of survivors treated with surgery to the chest and $6 \%$ treated with thoracic radiotherapy reported a chest wall abnormality.

In a multivariable regression, the following factors remained independently associated with chest wall abnormalities: male sex (odds ratio [OR] 1.8, 95\% Cl 1.0-3.3), older age at cancer diagnosis (OR $2.5,95 \% \mathrm{Cl} 1.0-6.1)$, lymphoma (OR 3.8, 95\%Cl 1.2-11.4), CNS tumor (OR 9.5, 95\%Cl 3.0-30.1), thoracic 
medRxiv preprint doi: https://doi.org/10.1101/2021.01.24.21250393; this version posted January 26, 2021. The copyright holder for this preprint (which was not certified by peer review) is the author/funder, who has granted medRxiv a license to display the preprint in

All rights reserved. No reuse allowed without permission.

radiotherapy (OR $2.0,95 \% \mathrm{Cl} 1.0-4.2)$, surgery to the chest (OR 4.5, 95\%Cl

1.8-11.5), and chemotherapy (OR 2.9, 95\%Cl 1.0-8.1) (table 2).

\section{Telephone interviews}

Among the 48 survivors who reported chest wall abnormalities, 25 survivors were eligible for being interviewed and 20 participated (80\%), 18 confirmed to have a chest wall abnormality (Table 3 ). When asked in more detail, $85 \%$ $(17 / 20)$ described thoracic wall deformities, $60 \%(12 / 20)$ a deformation of the spine, and $70 \%(14 / 20)$ scars on the chest wall. Most survivors $(80 \% ; 16 / 20)$ reported multiple problems (Figure 1 and Table 3). Thoracic wall deformities included pectus excavatum, pectus carinatum and unspecified thoracic asymmetries, missing or deformed ribs, and deformation of the breasts. Deformation of the spine included scoliosis, hyper kyphosis, and hyper lordosis.

We also asked survivors whether the chest wall abnormalities affected their daily life and if they had sought medical attention. Among the 20 survivors interviewed, 13 survivors said that the chest wall abnormality affected respiration, flexibility, and activities of daily life, caused cosmetic problems, or pain (table 3). Fifteen survivors had sought medical attention. Fourteen consulted a doctor (10 visited one specialist only and four visited multiple specialists). Specialists included general practitioners, pediatric oncologists, orthopedists, chiropractors, surgeons, sport physicians or rheumatologists. Nine survivors underwent diagnostic testing, six had a chest x-ray only and three a chest $\mathrm{x}$-rays and lung function tests. One survivor had needed an operation, and six had been treated by physiotherapists (table 3). 
medRxiv preprint doi: https://doi.org/10.1101/2021.01.24.21250393; this version posted January 26, 2021. The copyright holder for this preprint (which was not certified by peer review) is the author/funder, who has granted medRxiv a license to display the preprint in

\section{Literature Review}

Of 2,167 potentially relevant articles identified, we excluded 1,935 articles after screening of title and abstracts, leaving 244 articles for full text screening. Of those, we excluded a further 232 articles that did not meet inclusion criteria (Supplementary figure S3). We summarized the remaining in table 4. Among these, only two investigated in an unselected cohort of survivors with regard to cancer diagnosis and treatment. ${ }^{11,12}$ Both used postal questionnaires (the Swiss and North American Childhood Cancer Survivor Studies) and found a prevalence of chest wall abnormalities of $2.0 \%{ }^{12}$ and $1.3 \%{ }^{11}$. Six studies focused on survivors of selected cancer diagnoses; one on chest wall sarcoma, ${ }^{1}$ one on CNS tumours, ${ }^{10}$ two on neuroblastoma, ${ }^{2,9}$ and two on Wilms tumour. ${ }^{3,4}$ Four studies focused on specific cancer treatments only: one on operations of solid tumours ${ }^{5}$ and three on irradiation including at least parts of the thorax ${ }^{6-8}$. Scoliosis was reported mainly in survivors of neuroblastoma and Wilms tumor, and after radiotherapy of the spine $e^{2-4,8,9}$. Breast asymmetries with severe cosmetic deformities were described in $35 \%$ of female survivors after radiation to the spine ${ }^{6}$. Breast underdevelopment was reported in $11 \%$ of survivors who had undergone chest radiation. ${ }^{5}$ Scars resulting in psychological problems was described in $80 \%$ of survivors of solid malignancies after surgery. ${ }^{5}$ Asymmetries of the ribs, scapula and thorax were described after neuroblastoma, Wilms tumor, and chest and abdominal radiotherapy. ${ }^{2,5,7}$ Studies that focused on selected outcomes or treatments reported a higher prevalence of chest wall abnormalities than studies based on unselected survivor cohorts (table 4). 
medRxiv preprint doi: https://doi.org/10.1101/2021.01.24.21250393; this version posted January 26, 2021. The copyright holder for this preprint (which was not certified by peer review) is the author/funder, who has granted medRxiv a license to display the preprint in

\section{Discussion}

This is the first study to describe self-reported chest wall abnormalities in an unselected, representative sample of childhood cancer survivors in detail, and to validate answers in a structured interview. Two percent of all survivors reported a chest wall abnormality. We found a broad range of problems that was summarized as chest wall abnormalities. More than half of interviewed survivors were affected in their daily lives and three quarters had required medical attention.

A strength of this study is, that we clarified types of chest wall abnormalities and their impact on daily life by directly interviewing survivors. Survivors could explain their problems and we could inquire about the impact of chest wall abnormalities. We were able to reach $80 \%$ of eligible survivors who had reported a chest wall abnormality in the SCCSS questionnaire. Participants did not differ from nonparticipants (results not shown) and a previous study concluded that response bias in the SCCSS did not markedly influence prevalence estimates. ${ }^{18}$

The prevalence of chest wall abnormalities in this study and in a previously published study from Switzerland with an overlapping population ${ }^{12}$ was slightly higher than in to the North American Childhood Cancer Survivors Study $(2.0 \%$ versus $1.3 \%$ ), especially for CNS tumor survivors (4.0\% versus $0.4 \%) .{ }^{11,12}$ Treatment-related factors like the frequency and cumulative dose of thoracic radiotherapy, such as spinal radiation in CNS tumor patients, might differ between countries and help to explain such differences in prevalence of chest wall abnormalities. Smaller studies and case series reported chest wall abnormalities in selected subgroups of survivors and found a wide range of prevalences (table 3). ${ }^{1-8}$

Risk factors for chest wall abnormalities in survivors vary between studies. Our study is the first to report older age at diagnosis (16-20 years) as a risk factor for 
medRxiv preprint doi: https://doi.org/10.1101/2021.01.24.21250393; this version posted January 26, 2021. The copyright holder for this preprint (which was not certified by peer review) is the author/funder, who has granted medRxiv a license to display the preprint in All rights reserved. No reuse allowed without permission.

chest wall abnormalities. Peak bone growth velocity and increase of peak bone mass happen during puberty, ${ }^{19}$ therefore cancer treatment during this vulnerable time may affect the development of the spine and thoracic wall more severely than treatment earlier in childhood. CNS tumor survivors were most likely to report chest wall abnormalities. CNS tumors are often treated with radiotherapy to the spine, which another risk factor identified in our study (OR $2.0 ; 95 \% \mathrm{Cl} 1.0-4.2)$, in the North American Childhood Cancer Survivor Study (rate ratio 5.0), ${ }^{11}$ and in other studies. ${ }^{5-8}$ Also, CNS tumor survivors often suffer from co-morbidities that include small stature, functional deficits, endocrine diseases, fatigue, and psychological problems, ${ }^{20}$ which might lead to a higher subjective burden by chest wall abnormalities compared to other survivor groups.

We could validate chest wall abnormalities in eighteen of 20 survivors who indicated a chest wall abnormality in the SCCSS questionnaire. Two survivors had scars only, which they reported as chest wall abnormalities and 12 had both, scars and chest wall abnormalities. This suggests that not all survivors understood the term "chest wall abnormality" as was intended by the questionnaire. We suggest that future questionnaires describe chest wall abnormalities in more detail or use open questions to further assess the type of chest wall abnormality. For physicians involved in follow-up care of childhood cancer survivors awareness of chest wall abnormalities should be raised and clinical examinations of performed to quantify the extent of individual problems and limitations.

Many participants were affected in daily life by chest wall abnormalities, which reflects the severity of this rare late effect after childhood cancer treatment. The most common complaints impaired flexibility and physical fitness. An interdisciplinary treatment approach could help improve these issues. Early physiotherapy could be 
medRxiv preprint doi: https://doi.org/10.1101/2021.01.24.21250393; this version posted January 26, 2021. The copyright holder for this preprint (which was not certified by peer review) is the author/funder, who has granted medRxiv a license to display the preprint in All rights reserved. No reuse allowed without permission.

used in survivors at risk of developing chest wall abnormalities to improve late functional outcomes and might reduce pain.

\section{Conclusion}

In conclusion, this study suggests that even though chest wall abnormalities are rare in the entire survivor population, they have a considerable impact on survivors lives. Physicians should pay close attention to these problems during follow-up care. 
medRxiv preprint doi: https://doi.org/10.1101/2021.01.24.21250393; this version posted January $26,2021$. The copyright holder for this preprint (which was not certified by peer review) is the author/funder, who has granted medRxiv a license to display the preprint in perpetuity.

All rights reserved. No reuse allowed without permission.

\section{References}

1. Lucas JT, Jr., Fernandez-Pineda I, Tinkle CL, et al. Late toxicity and outcomes following radiation therapy for chest wall sarcomas in pediatric patients. Practical radiation oncology. 2017;7(6):411-417.

2. Perwein $\mathrm{T}$, Lackner $\mathrm{H}$, Sovinz $\mathrm{P}$, et al. Survival and late effects in children with stage 4 neuroblastoma. Pediatric blood \& cancer. 2011;57(4):629-635.

3. Trobs RB, Hansel M, Friedrich T, Bennek J. A 23-year experience with malignant renal tumors in infancy and childhood. European journal of pediatric surgery : official journal of Austrian Association of Pediatric Surgery ... [et al] = Zeitschrift fur Kinderchirurgie. 2001;11(2):92-98.

4. Heaston DK, Libshitz HI, Chan RC. Skeletal effects of megavoltage irradiation in survivors of Wilms' tumor. AJR. American journal of roentgenology. 1979;133(3):389-395.

5. Pinter AB, Hock A, Kajtar P, Dober I. Long-term follow-up of cancer in neonates and infants: a national survey of 142 patients. Pediatric surgery international. 2003;19(4):233-239.

6. Butler MS, Robertson WW, Jr., Rate W, D'Angio GJ, Drummond DS. Skeletal sequelae of radiation therapy for malignant childhood tumors. Clinical orthopaedics and related research. 1990(251):235-240.

7. Taylor RE. Morbidity from abdominal radiotherapy in the First United Kingdom Children's Cancer Study Group Wilms' Tumour Study. United Kingdom Children's Cancer Study Group. Clinical oncology (Royal College of Radiologists (Great Britain)). 1997;9(6):381-384.

8. Venkatramani R, Kamath S, Wong K, et al. Correlation of clinical and dosimetric factors with adverse pulmonary outcomes in children after lung irradiation. International journal of radiation oncology, biology, physics. 2013;86(5):942-948.

9. Utriainen $P$, Vatanen A, Toiviainen-Salo S, ... Skeletal outcome in long-term survivors of childhood high-risk neuroblastoma treated with high-dose therapy and autologous stem cell rescue. Bone marrow .... 2017.

10. Huang TT, Chen Y, Dietz AC, et al. Pulmonary outcomes in survivors of childhood central nervous system malignancies: a report from the Childhood Cancer Survivor Study. Pediatric blood \& cancer. 2014;61(2):319-325.

11. Mertens AC, Yasui Y, Liu Y, et al. Pulmonary complications in survivors of childhood and adolescent cancer. A report from the Childhood Cancer Survivor Study. Cancer. 2002;95(11):2431-2441.

12. Kasteler R, Weiss A, Schindler M, et al. Long-term pulmonary disease among Swiss childhood cancer survivors. Pediatric blood \& cancer. 2018;65(1).

13. Michel G, von der Weid NX, Zwahlen M, Adam M, Rebholz CE, Kuehni CE. The Swiss Childhood Cancer Registry: rationale, organisation and results for the years 2001-2005. Swiss medical weekly. 2007;137(35-36):502-509.

14. Kuehni CE, Rueegg CS, Michel G, et al. Cohort profile: the Swiss childhood cancer survivor study. International journal of epidemiology. 2012;41(6):15531564.

15. Robison LL, Mertens AC, Boice JD, et al. Study design and cohort characteristics of the Childhood Cancer Survivor Study: a multi-institutional collaborative project. Medical and pediatric oncology. 2002;38(4):229-239.

16. Hawkins MM, Lancashire ER, Winter DL, et al. The British Childhood Cancer Survivor Study: Objectives, methods, population structure, response rates and 
medRxiv preprint doi: https://doi.org/10.1101/2021.01.24.21250393; this version posted January 26, 2021. The copyright holder for this preprint (which was not certified by peer review) is the author/funder, who has granted medRxiv a license to display the preprint in

All rights reserved. No reuse allowed without permission.

initial descriptive information. Pediatric blood \& cancer. 2008;50(5):10181025.

17. Steliarova-Foucher E, Stiller C, Lacour B, Kaatsch P. International Classification of Childhood Cancer, third edition. Cancer. 2005;103(7):14571467.

18. Rueegg CS, Gianinazzi ME, Michel G, et al. No evidence of response bias in a population-based childhood cancer survivor questionnaire survey - Results from the Swiss Childhood Cancer Survivor Study. PloS one. 2017;12(5):e0176442.

19. Stagi S, Cavalli L, lurato C, Seminara S, Brandi ML, de Martino M. Bone metabolism in children and adolescents: main characteristics of the determinants of peak bone mass. Clin Cases Miner Bone Metab. 2013;10(3):172-179.

20. Turner CD, Rey-Casserly C, Liptak CC, Chordas C. Late effects of therapy for pediatric brain tumor survivors. J Child Neurol. 2009;24(11):1455-1463. 
medRxiv preprint doi: https://doi.org/10.1101/2021.01.24.21250393; this version posted January 26, 2021. The copyright holder for this preprint (which was not certified by peer review) is the author/funder, who has granted medRxiv a license to display the preprint in perpetuity.

All rights reserved. No reuse allowed without permission.

TABLE 1 Characteristics of Swiss childhood cancer survivors overall and of those reporting chest wall abnormalities.

\begin{tabular}{|c|c|c|c|c|c|}
\hline & \multicolumn{2}{|c|}{$\begin{array}{l}\text { Overall } \\
N=2,382 \\
(100 \%) \\
\end{array}$} & \multicolumn{3}{|c|}{$\begin{array}{l}\text { Survivors reporting chest wall abnormalities } \\
\mathrm{N}=48 \\
(2.0 \%, 95 \% \mathrm{Cl} 1.5-2.7)\end{array}$} \\
\hline & $\mathrm{n}$ & $\%^{a}$ & $\mathrm{n}$ & $\%^{\mathrm{b}}$ & $(95 \% \mathrm{Cl})$ \\
\hline \multicolumn{6}{|l|}{ Sex } \\
\hline Female & 1,111 & $46.6 \%$ & 16 & $1.4 \%$ & $(0.8-2.3)$ \\
\hline Male & 1,271 & $53.4 \%$ & 32 & $2.5 \%$ & $(1.8-3.5)$ \\
\hline \multicolumn{6}{|l|}{ Age at diagnosis (years) } \\
\hline $0-5$ & 1,108 & $46.5 \%$ & 20 & $1.8 \%$ & $(1.2-2.8)$ \\
\hline $6-10$ & 521 & $21.9 \%$ & 7 & $1.3 \%$ & $(0.6-2.8)$ \\
\hline $11-15$ & 540 & $22.7 \%$ & 12 & $2.2 \%$ & $(1.3-3.9)$ \\
\hline $16-20$ & 213 & $8.9 \%$ & 9 & $4.2 \%$ & $(2.2-7.9)$ \\
\hline Median (IQR) age at study (years) & 31.1 & $(24.6-38.2)$ & 32.1 & $(25.8-$ & 8.1) \\
\hline \multicolumn{6}{|l|}{ Year of diagnosis } \\
\hline $1976-1990$ & 845 & $35.5 \%$ & 18 & $2.1 \%$ & $(1.3-3.4)$ \\
\hline $1991-2005$ & 1,537 & $64.5 \%$ & 30 & $2.0 \%$ & $(1.4-2.8)$ \\
\hline \multicolumn{6}{|l|}{ Diagnosis } \\
\hline I: Leukemia & 773 & $32.5 \%$ & 5 & $0.6 \%$ & $(0.2-1.5)$ \\
\hline II: Lymphoma & 428 & $17.9 \%$ & 16 & $3.7 \%$ & $(2.3-6.0)$ \\
\hline III: CNS tumor & 345 & $14.5 \%$ & 13 & $3.8 \%$ & $(2.2-6.4)$ \\
\hline IV-XII: Other tumors & 836 & $35.1 \%$ & 14 & $1.7 \%$ & $(1.0-2.8)$ \\
\hline \multicolumn{6}{|l|}{ Thoracic radiotherapy ${ }^{c}$} \\
\hline No & 2,075 & $87.1 \%$ & 31 & $1.5 \%$ & $(1.1-2.1)$ \\
\hline Yes & 307 & $12.9 \%$ & 17 & $5.5 \%$ & $(3.5-8.7)$ \\
\hline \multicolumn{6}{|l|}{ Surgery to the chest ${ }^{d}$} \\
\hline No & 2,290 & $96.1 \%$ & 41 & $1.8 \%$ & $(1.3-2.4)$ \\
\hline Yes & 92 & $3.9 \%$ & 7 & $7.6 \%$ & $(3.7-15.2)$ \\
\hline \multicolumn{6}{|l|}{ Any chemotherapy } \\
\hline No & 414 & $17.4 \%$ & 6 & $1.4 \%$ & $(0.7-3.2)$ \\
\hline Yes & 1,968 & $82.6 \%$ & 42 & $2.1 \%$ & $(1.6-2.9)$ \\
\hline
\end{tabular}

Abbreviations: $\mathrm{Cl}$, confidence interval; $\mathrm{N}$, number

a Column percentages are given

${ }^{b}$ Row percentages are given

c Including the following radiation fields: total body irradiation, mantle field, thorax, lungs, mediastinum, or thoracic spine

d Including surgery to clavicle, scapulae and ribs, tumor excision from soft tissue on thorax, muscles on thorax, spine of thorax, and tumor or lymph node biopsy on the chest wall 
medRxiv preprint doi: https://doi.org/10.1101/2021.01.24.21250393; this version posted January $26,2021$. The copyright holder for this preprint (which was not certified by peer review) is the author/funder, who has granted medRxiv a license to display the preprint in

All rights reserved. No reuse allowed without permission.

TABLE 2 Demographic and cancer-related risk factors for chest wall abnormalities in Swiss childhood cancer survivors.

Chest wall abnormalities $(n=48)$

\begin{tabular}{|c|c|c|c|c|c|c|}
\hline Total $\mathrm{N}=2,382$ & OR $_{\text {crude }}{ }^{\mathrm{a}}$ & $(95 \% \mathrm{Cl})$ & $\mathbf{P}^{\mathrm{b}}$ & $\mathrm{OR}_{\mathrm{adj}}{ }^{\mathrm{c}}$ & $(95 \% \mathrm{Cl})$ & $\mathbf{P}^{\mathbf{c}}$ \\
\hline Sex & & & 0.059 & & & 0.062 \\
\hline Female & Ref. & & & Ref. & & \\
\hline Male & 1.8 & $(1.0-3.2)$ & & 1.8 & $(1.0-3.3)$ & \\
\hline Age at diagnosis (years) & & & 0.125 & & & 0.017 \\
\hline $0-5$ & Ref. & & & Ref. & & \\
\hline $6-10$ & 0.7 & $(0.3-1.8)$ & & 0.5 & $(0.2-1.2)$ & \\
\hline $11-15$ & 1.2 & $(0.6-2.5)$ & & 0.7 & $(0.3-1.6)$ & \\
\hline $16-20$ & 2.4 & $(1.1-5.3)$ & & 2.5 & $(1.0-6.1)$ & \\
\hline Year of diagnosis & & & 0.768 & & & 0.602 \\
\hline $1976-1990$ & Ref. & & & Ref. & & \\
\hline $1991-2005$ & 0.9 & $(0.5-1.7)$ & & 0.8 & $(0.5-1.6)$ & \\
\hline Diagnosis & & & $<0.001$ & & & $<0.001$ \\
\hline I: Leukemia & Ref. & & & Ref. & & \\
\hline II: Lymphoma & 6.0 & $(2.2-16.4)$ & & 3.8 & $(1.2-11.4)$ & \\
\hline III: CNS tumor & 6.0 & $(2.1-17.0)$ & & 9.5 & $(3.0-30.1)$ & \\
\hline IV-XII: Other tumors & 2.6 & $(0.9-7.3)$ & & 2.1 & $(0.7-6.1)$ & \\
\hline Thoracic radiotherapy ${ }^{d}$ & & & $<0.001$ & & & 0.058 \\
\hline No & Ref. & & & Ref. & & \\
\hline Yes & 3.9 & $(2.1-7.1)$ & & 2.0 & $(1.0-4.2)$ & \\
\hline $\begin{array}{l}\text { Surgery to the chest } \\
\text { No } \\
\text { Yes }\end{array}$ & $\begin{array}{l}\text { Ref. } \\
4.5\end{array}$ & $(2.0-10.4)$ & 0.002 & $\begin{array}{l}\text { Ref. } \\
4.5\end{array}$ & $(1.8-11.5)$ & 0.004 \\
\hline $\begin{array}{l}\text { Any chemotherapy } \\
\text { No } \\
\text { Yes }\end{array}$ & $\begin{array}{l}\text { Ref. } \\
1.5\end{array}$ & $(0.6-3.5)$ & 0.348 & $\begin{array}{l}\text { Ref. } \\
2.9\end{array}$ & $(1.0-8.1)$ & 0.029 \\
\hline
\end{tabular}

Abbreviations: $\mathrm{Cl}$, confidence interval; OR, Odds ratio; N, number; P, P-value

a Odds ratio from univariable logistic regression analysis

${ }^{\mathrm{b}} \mathrm{P}$-values calculated from likelihood-ratio tests comparing survivors with and without chest wall abnormality

${ }^{c}$ Odds ratio from multivariable logistic regression analysis, model adjusted for all factors shown

${ }^{d}$ Including the following radiation fields: total body irradiation, mantle field, thorax, lungs, mediastinum, or thoracic spine

e Including surgery to clavicle, scapulae and ribs, tumor excision from soft tissue on thorax, muscles on thorax, spine of thorax, and tumor or lymph node biopsy on the chest wall 
medRxiv preprint doi: https://doi.org/10.1101/2021.01.24.21250393; this version posted January $26,2021$. The copyright holder for this preprint (which was not certified by peer review) is the author/funder, who has granted medRxiv a license to display the preprint in All rights reserved. No reuse allowed without permission.

TABLE 3 Impact of chest wall abnormalities on the daily life of survivors, and medical

attention required because of chest wall abnormality.

$\mathbf{N}=\mathbf{2 0} \quad$ Proportion (\%)

\section{Impact of chest wall abnormalities on the daily life}

Any impact

$\begin{array}{ll}13 & 65 \% \\ 8 & 40 \% \\ 7 & 35 \% \\ 6 & 30 \% \\ 6 & 30 \% \\ 6 & 30 \%\end{array}$

\section{Required medical attention because of chest wall abnormality}

Any medical attention

$\begin{array}{ll}15 & 75 \% \\ 14 & 70 \% \\ 10 & 50 \% \\ 4 & 20 \% \\ 9 & 45 \% \\ 6 & 30 \% \\ 3 & 15 \% \\ 1 & 5 \% \\ 6 & 30\end{array}$

Consultation ${ }^{a}$

1 specialist visited

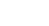

$>1$ specialist visited

Diagnostic investigation ${ }^{b}$

Chest X-ray

Chest X-ray + lung function test

Operations

(1)

Physiotherapy

Abbreviations: N, number; Respiration, any respiratory impairment; Flexibility, impairment of flexibility; Activities of daily living, inability or problems when performing activities of daily living such as housekeeping; Cosmetic, disturbed by the cosmetic appearance of the chest wall abnormality; Pain, any pain because of the chest wall abnormality; Consultation, ever consulted a medical doctor because of the chest wall abnormality; Diagnostic investigation, had further diagnostic testing because of the chest wall abnormality (e.g., chest x-ray, lung function tests); Operations, had an operation because of the chest wall abnormality; Physiotherapy, visited physical therapy because of the chest wall abnormalities

a Survivors reported consultations with: general practitioners $n=5$, pediatric oncologists $n=4$, oncologist $n=1$, orthopedist $n=3$, chiropractic's $n=1$, surgeons $n=1$, sports physicians $n=1$, rheumatologist $n=1$ 
Table 4 Literature summary of systematic review on chest wall abnormalities in childhood cancer survivors

\begin{tabular}{|c|c|c|c|c|c|c|c|c|c|}
\hline \multirow{2}{*}{$\begin{array}{l}\text { First author, } \\
\text { year, country }\end{array}$} & \multirow{2}{*}{$\begin{array}{l}\text { Treatment } \\
\text { era }\end{array}$} & \multirow[t]{2}{*}{ Inclusion criteria } & \multirow{2}{*}{$\begin{array}{l}\text { Type of outcome } \\
\text { assessment }\end{array}$} & \multirow{2}{*}{$\begin{array}{l}\text { Sample } \\
\text { Size (n) }\end{array}$} & \multirow{2}{*}{$\begin{array}{l}\text { Age at } \\
\text { diagnosis in } \\
\text { years }\end{array}$} & \multirow{2}{*}{$\begin{array}{l}\text { Years of } \\
\text { follow-up }\end{array}$} & \multicolumn{3}{|c|}{ Chest wall abnormality } \\
\hline & & & & & & & Definition & $n$ & $\%$ \\
\hline
\end{tabular}

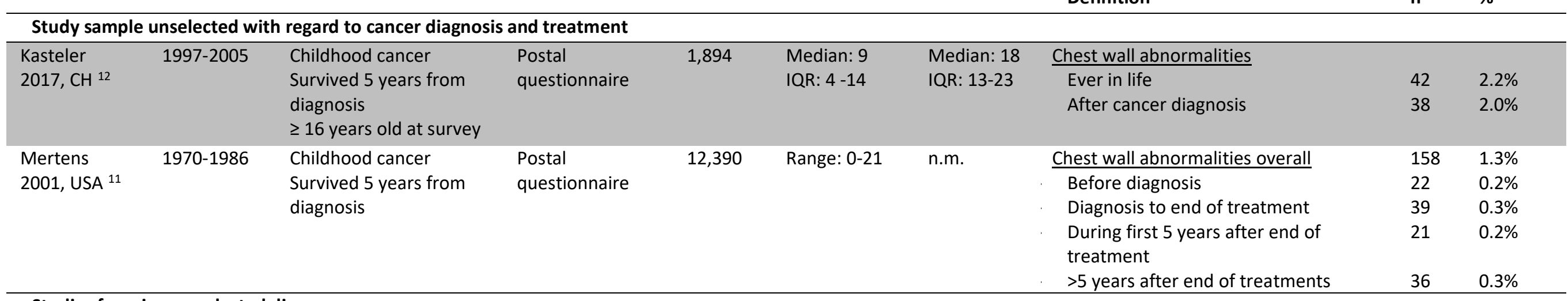

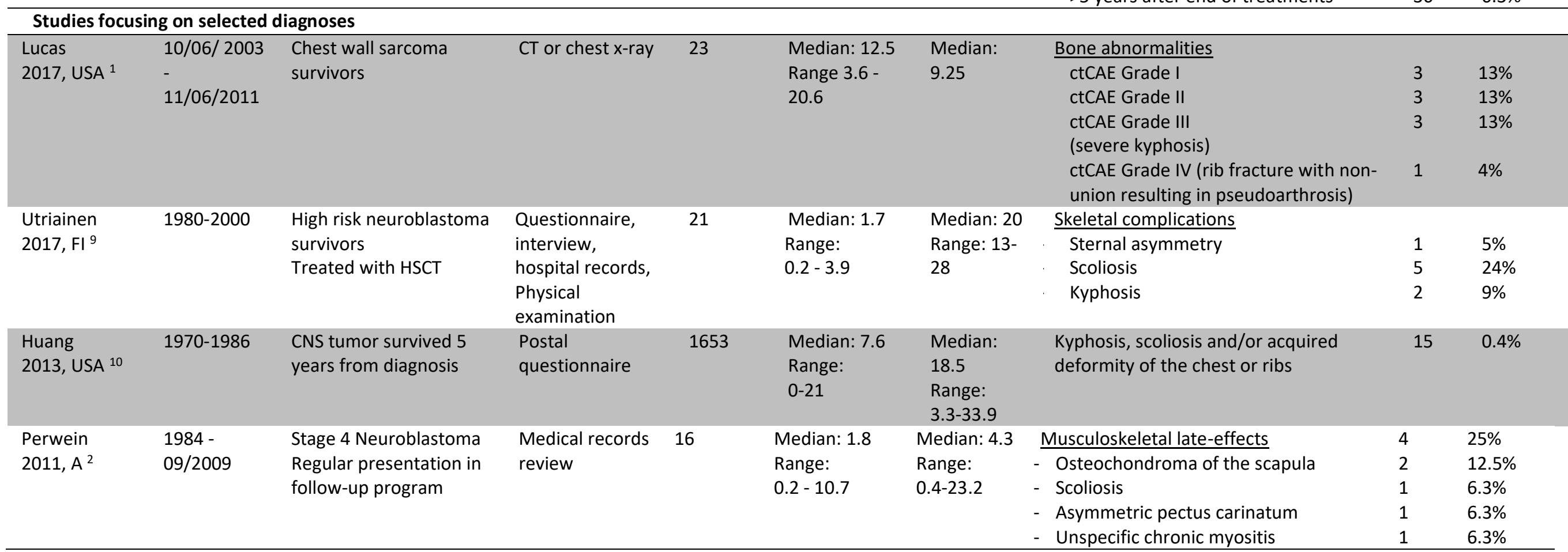




\begin{tabular}{|c|c|c|c|c|c|c|c|c|c|}
\hline $\begin{array}{l}\text { Tröbs } \\
2001, D^{3}\end{array}$ & $\begin{array}{l}01 / 1974- \\
12 / 1988\end{array}$ & Wilms tumor & $\begin{array}{l}\text { Medical records } \\
\text { review }\end{array}$ & 49 & Median: 2.6 & n.m & $\begin{array}{l}\text { - Chest wall deformity } \\
\text { - Deformations of the spine (scoliosis, } \\
\text { kyphosis) and lumbar muscle tissue } \\
\text { atrophy }\end{array}$ & $\begin{array}{l}3 \\
35\end{array}$ & $\begin{array}{l}6 \% \\
71 \%\end{array}$ \\
\hline \multirow{5}{*}{$\begin{array}{l}\text { Heaston } \\
\text { 1979, USA }{ }^{4}\end{array}$} & & and serial radiographs & & & & & Kyphoscoliosis & 7 & $28 \%$ \\
\hline & & available & & & & & Diminution or loss of lumbar lordosis & 9 & $36 \%$ \\
\hline & & & & & & & $\frac{\text { Extra axial skeletal alterations }}{\text { Hypoplasia of the pelvis and/or thorax }}$ & 2 & $8 \%$ \\
\hline & & & & & & & & 16 & $64 \%$ \\
\hline & & & & & & & & 13 & $52 \%$ \\
\hline
\end{tabular}

\begin{tabular}{|c|c|c|c|c|c|c|c|c|c|}
\hline \multicolumn{10}{|c|}{ Studies focusing on specific cancer treatments } \\
\hline $\begin{array}{l}\text { Venkatramani } \\
\text { 2013, USA }{ }^{8}\end{array}$ & $1999-2009$ & $\begin{array}{l}\text { Childhood cancer } \\
\text { Radiotherapy to the } \\
\text { lungs without total body } \\
\text { irradiation or whole lung } \\
\text { irradiation }\end{array}$ & $\begin{array}{l}\text { Medical records } \\
\text { review }\end{array}$ & 109 & $\begin{array}{l}\text { Median: } 13.4 \\
\text { Range: } 0.01- \\
19.9\end{array}$ & $\begin{array}{l}\text { Median: } 2.5 \\
\text { Range: } \\
0.2-9\end{array}$ & $\begin{array}{l}\text { Chest wall abnormality } \\
\text { - Scoliosis } \\
\text { - Kyphosis } \\
\text { - Hypoplasia of chest wall }\end{array}$ & $\begin{array}{l}11 \\
11 \\
2 \\
1\end{array}$ & $\begin{array}{l}10 \% \\
10 \% \\
2 \% \\
1 \%\end{array}$ \\
\hline $\begin{array}{l}\text { Pintér } \\
\text { 2003, HU } 5\end{array}$ & $\begin{array}{l}\text { 01/01/1975 } \\
- \\
31 / 12 / 1983\end{array}$ & $\begin{array}{l}\text { Childhood cancer } \\
\text { Operated for solid } \\
\text { malign tumor excluding } \\
\text { retinoblastomas and } \\
\text { CNS tumors }\end{array}$ & $\begin{array}{l}\text { Personal } \\
\text { interviews / } \\
\text { questionnaires }\end{array}$ & 79 & $\begin{array}{l}\mathrm{N}=17<1 \text { year } \\
\text { old } \\
\mathrm{N}=62<29 \\
\text { days old: }\end{array}$ & $\begin{array}{l}\text { Mean: } 20 \\
\text { Range: } 16- \\
25\end{array}$ & $\begin{array}{ll}\begin{array}{l}\text { Subgroup analysis per treatment group } \\
\text { Surgical intervention ( } \mathrm{n}=15 \text { ) }\end{array} \\
-\quad \text { Thoracic deformity } \\
-\quad \text { Scar formation resulting in } \\
\text { psychological problems } \\
\text { Multimodal therapy (surgical, chemo- } \\
\text { and radiotherapy, } \mathrm{n}=64 \text { ) } \\
-\quad \text { Skin lesion following radiotherapy } \\
-\quad \text { Muscular deformity } \\
-\quad \text { Bone morbidity } \\
\text { - } \quad \text { Decreased physical ability to work } \\
-\quad \text { Thoracic deformity } \\
-\quad \text { Breast underdevelopment } \\
-\quad \text { Spinal deformity } \\
-\quad \text { Scar formation resulting in } \\
\quad \text { psychological problems }\end{array}$ & $\begin{array}{l}2 \\
7 \\
5 \\
3 \\
4 \\
7 \\
22 \\
12\end{array}$ & $\begin{array}{l}3 \% \\
11 \% \\
8 \% \\
\\
5 \% \\
6 \% \\
11 \% \\
34 \% \\
19 \%\end{array}$ \\
\hline
\end{tabular}




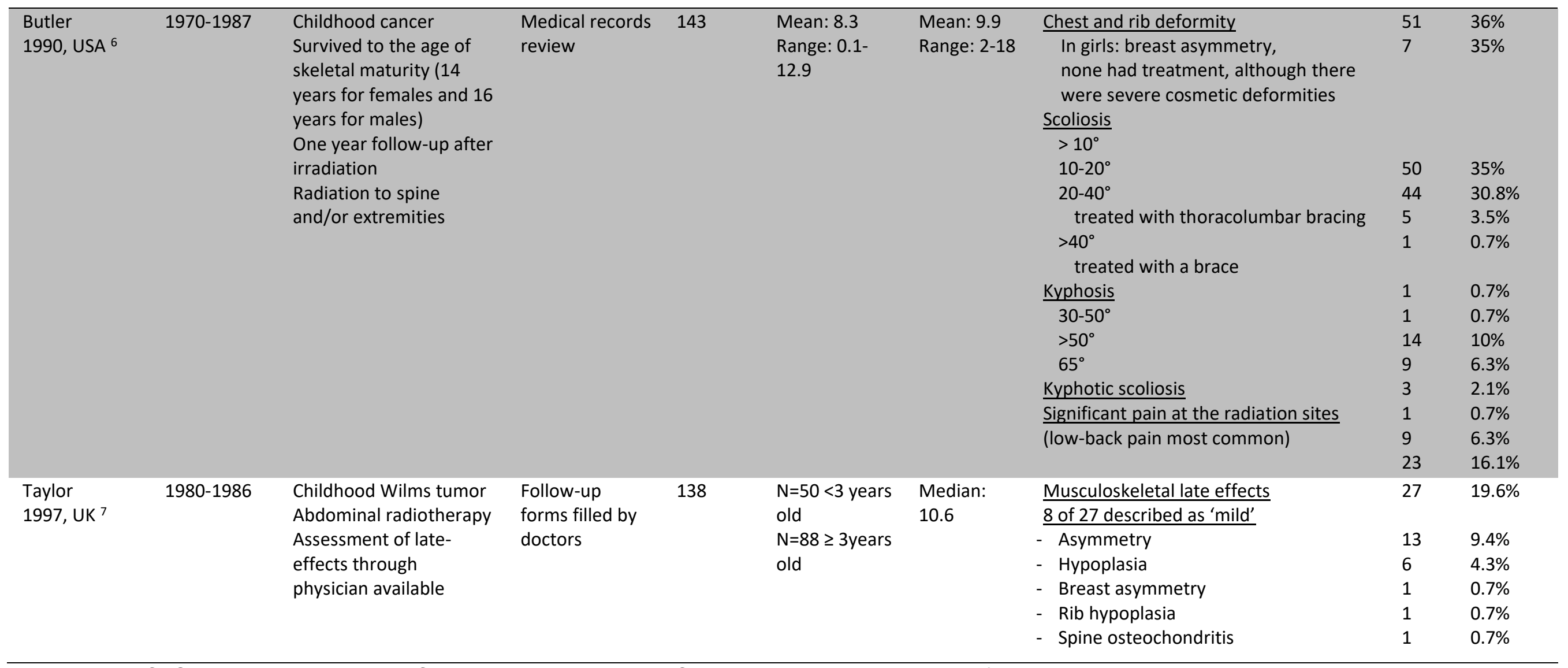

Abbreviation: CNS, central nervous system; CT, computer tomography; ctCAE, common terminology criteria for adverse events; $n$.m, not mentioned 
medRxiv preprint doi: https://doi.org/10.1101/2021.01.24.21250393; this version posted January $26,2021$. The copyright holder for this preprint (which was not certified by peer review) is the author/funder, who has granted medRxiv a license to display the preprint in

All rights reserved. No reuse allowed without permission.

Scars on the chest wall $(n=14,70 \%)$

Thoracic wall deformity $(n=17,85 \%)$

Deformation of the spine $(n=12,60 \%)$

Figure 1. Proportional Venn-diagram showing reported types and overlap of chest wall abnormalities in childhood cancer survivors in the telephone interview. 